\title{
Nephroprotective action of glycosaminoglycans: why the pharmacological properties of sulodexide might be reconsidered
}

This article was published in the following Dove Press journal: International Journal of Nephrology and Renovascular Disease 3 July 2010

Number of times this article has been viewed

\author{
Antonio $V$ Gaddi' \\ Arrigo FG Cicero' \\ Giovanni Gambaro² \\ 'Atherosclerosis and Metabolic \\ disease Research Unit, Internal \\ Medicine, Aging and Kidney diseases \\ Dept., University of Bologna, Italy; \\ ${ }^{2}$ Nephrology and Dialysis Unit, \\ Gemelli University Hospital, Sacred \\ Heart Catholic University, Rome, Italy
}

Correspondence:Antonio V Gaddi Atherosclerosis and Metabolic Disease Research Unit, Internal Medicine, Aging and Kidney Diseases Dept., Sant'Orsola-Malpighi University Hospital, Via Massarenti 9, 40I38 Bologna, Italy

$\mathrm{Tel}+3905 \mathrm{I} 6363938$

Fax +39 05I 390646

Email antonio.gaddi@unibo.it

\begin{abstract}
A relatively large body of evidence supports the notion that glomerular capillary wall and mesangial alterations in diabetic nephropathy involve biochemical alterations of glycoproteins in these structures. Evidence in experimental animals rendered diabetic reveals that the administration of heparin and other anionic glycoproteins can effectively prevent the biochemical alterations that promote albuminuria. Moreover, angiotensin II inhibits heparan sulfate synthesis, while heparins modulate angiotensin II signaling in glomerular cells, inhibiting aldosterone synthesis and lowering proteinuria in diabetes patients. Sulodexide, a mixture of heparin and dermatan sulfate, appears to be a promising treatment for diabetic proteinuria partially resistant to renin-angiotensin system blocking agents. Sulodexide prevents heparan sulfate degradation, thus allowing reconstruction of heparan sulfate content and restoration of glomerular basement membrane ionic permselectivity. The antiproteinuric effect appears to be mainly related to the basal proteinuria and consequently to the duration of treatment in a relatively large number of small clinical trials. On the other hand, several sulodexide pharmacodynamic properties could improve the prognosis of chronic kidney disease patients, also independently from its antiproteinuric effect. However, sulodexide development as an antiproteinuric drug needs to be continued, in order to define which kind of patients could better respond to this treatment.
\end{abstract}

Keywords: glycosaminoglycans, sulodexide, albuminuria, proteinuria, diabetic nephropathy

\section{Introduction}

Diabetes mellitus is strongly associated with cardiovascular disease morbidity and mortality, accelerating the vascular aging process and in particular the pathogenesis of atherosclerosis. Diabetic nephropathy is a highly important cause of morbidity and mortality in patients with type 1 and type 2 diabetes mellitus, either directly and as a risk factor for cardiovascular disease. ${ }^{1}$ In particular, diabetic kidney disease occurs in $20 \%$ to $40 \%$ of patients with diabetes mellitus and is the leading cause of chronic kidney disease and end-stage renal disease. ${ }^{2}$

Recent evidence shows that an early multipharmacological approach is able to slow the progression of diabetic nephropathy to end stage renal disease (ESRD), the disease rarely stops and slightly regresses just in few selected and optimally treated patients. ${ }^{3}$ In this context, there is a strong need for new agents able to significantly modify the patient disease history.

The aim of this review is to evaluate the potential role of glycosaminoglycans (and in particular sulodexide) as antiproteinuric and kidney protective drugs. 


\section{Glycosaminoglycans role in proteinuria management}

Glycosaminoglycans (GAGs) are long unbranched mucopolysaccharides consisting of a repeating disaccharide unit. Apart from hyaluronan, which is uniquely synthesized without a protein core and is "spun out" by enzymes at cell surfaces directly into the extracellular space, the other GAGs are usually added to protein cores in the Golgi apparatus to yield proteoglycans. ${ }^{4}$ It has been proposed that hemodynamic alterations and structural changes in glomerular basement membrane glycosaminoglycans may play a role in the pathogenesis of proteinuria. The glomerular filtration barrier consists of fenestrated glomerular endothelium, podocyte foot processes/slit diaphragms, and intervening glomerular basement membrane. Its characterization as both a size- and charge-selective barrier emerged from studies conducted decades ago. The charge selectivity phenomenon is receiving renewed attention now that the identities and mechanisms of synthesis of relevant molecules are known. ${ }^{5}$ Attention has focused on glomerular basement membrane heparan sulfate proteoglycans, long considered primary charge barrier components, even if recent in vivo manipulations of glomerular heparan sulfate proteoglycans redefined (but not excluded) their role or their anionic charge in glomerular filtration. ${ }^{6}$ In fact an experimental model of non-diabetic mice, knock-out for the Ext1 gene encoding a subunit of heparan sulfate co-polymerase, develops a proteinuria that is less impressive than that expected from the available knowledge on renal physiology. ${ }^{7}$ However, a relatively large body of evidence supports the notion that glomerular capillary wall and mesangial alterations in diabetic nephropathy involve pathobiochemical alterations of glycoproteins in these structures. Evidence in experimental animals rendered diabetic reveals that the administration of heparin and other anionic glycoproteins can effectively prevent the biochemical alterations that promote albuminuria. ${ }^{8}$ Moreover, in renal biopsies of different human primary proteinuric diseases, pronounced tubulointerstitial heparan sulfate proteoglycans alteration are evident and strongly related to the inflammatory processes. ${ }^{9}$

Moreover, GAGs strongly influence thickness, integrity and permselectivity of the endothelial glycocalyx, a luminal layer composed of several proteoglycans and a special class of heavily glycosylated glycoproteins. Glycocalyx composition is strongly alterated in diabetes patients, who typically show early sign of renal damage. The recent demonstration that angiopoietin-1 also modifies basal kidney-microvessel permeselectivity acting on the glomerular glycocalyx further supports the key role of this glycocalyx and glycocalyx composition on glomerular function. ${ }^{10}$

Angiotensin II receptor blockers are renin-angiotensin system (RAS) modulators with known antiproteinuric activity. ${ }^{11}$ Angiotensin II inhibits heparan sulfate synthesis, while heparins modulate angiotensin II signaling in glomerular cells, inhibiting aldosterone synthesis and lowering proteinuria in diabetes patients (but less in other forms of proteinuric renal diseases). ${ }^{12}$ In this context, heparinoids have been considered as potentially useful antiproteinuric drugs that could have synergistic effects with RAS modulator. ${ }^{13}$

\section{Sulodexide as an antiproteinuric agent: the available evidence}

Sulodexide is a highly purified mixture of GAGs composed of a fast-moving heparin fraction ( $80 \%$ ) and dermatan sulfate (20\%), with a low molecular weight, a high oral bioavailability, and antithrombotic and profibrinolytic activity. ${ }^{14}$ It also appears to be a promising treatment for diabetic proteinuria partially resistant to RAS blocking agents. ${ }^{15}$ Sulodexide concentrates in renal parenchyma for a long time after administration. ${ }^{16}$ From preliminary trials it has been supposed that sulodexide reduces albuminuria acting in vivo as a heparinase inhibitor that reaches the glomerular capillary wall and prevents heparan sulfate degradation, thus allowing reconstruction of heparan sulfate content and restoration of glomerular basement membrane ionic permselectivity. ${ }^{17}$

Recent in vitro experiments on umbelical human veins demostrated that sulodexide supplementation restores the glycocalyx structure and barrier properties by increasing the trans-endothelial albumin leakage induced by hyperglycemic conditions. ${ }^{18}$

The antiproteinuric effect appears to be mainly related to the basal proteinuria and consequently to the duration of treatment. ${ }^{19}$ Moreover, at least a part of the renal histological degradation observed in diabetes is related to inflammatory processes. Sulodexide seems to have powerful antinflammatory activity in experimental models..$^{20} \mathrm{In}$ a model of cultured human umbilical endothelial cells exposed to high glucose concentration, sulodexide suppresses cellular inflammation and prevents glucose cytotoxicity: ${ }^{21}$ sulodexide is able to reverse the glucose-related cell release of free oxygen radicals, monocyte chemotactic protein-1 (MCP-1) and interleukin-6 (IL-6), and the inactivation of cell-repairing mechanism enabling the exposition to glucose. Moreover, in rats with streptozocin-induced diabetes, sulodexide exerts direct endothelial protective effects. ${ }^{22}$ 
A large number of studies, mainly carried out in type 1 and 2 diabetes patients, have strongly suggested the potential role of sulodexide as an antiproteinuric agent (Table 1). The majority of these studies, however, were small, had an open design, were of short duration, and involved inhomogeneous patient categories. However, at least 15 out of 16 studies, involving 594 patients, reported a significant antiproteinuric effect of sulodexide.

It remains to be clarified if sulodexide could exert an additive antiproteinuric effect in patients treated with fully dosed angiotensin-converting enzyme inhibitor (ACEI) or an angiotensin receptor blocker (ARB).

In a pilot study, return to normoalbuminuria or a decrease in albumine:creatinine ratio (ACR) of at least $50 \%$ from the baseline value was achieved in $25.3 \%$ of patients with persistent albuminuria in spite of being treated with the maximum recommended dose of an ACEI or an ARB. ${ }^{23}$ Interestingly, a very favorable trend for an increased rate of therapeutic success was obtained in the sulodexide group receiving the daily dose of $200 \mathrm{mg}$ (33.3\% versus $15.4 \%$ of patients receiving

Table I Clinical trials testing antiproteinuric effects of sulodexide in diabetes patients

\begin{tabular}{|c|c|c|c|c|c|}
\hline $\begin{array}{l}\text { Number of } \\
\text { patients }\end{array}$ & $\begin{array}{l}\text { Type of } \\
\text { patients }\end{array}$ & Dose & $\begin{array}{l}\text { Duration of } \\
\text { treatment }\end{array}$ & Main results & References \\
\hline 18 & Type 2 diabetes & $\begin{array}{l}600 \text { lipoproteinlipase- } \\
\text { releasing units/day IV }\end{array}$ & 3 weeks & $\begin{array}{l}\text { Albuminuria fall in } 89 \% \text { of patients, } \\
\text { proteinuria normalization in the } \\
9 \text { microalbuminuric patients }\end{array}$ & Shestakova $^{19}$ \\
\hline 15 & Type I diabetes & $\begin{array}{l}600 \text { lipoproteinlipase- } \\
\text { releasing units/day IV }\end{array}$ & 3 weeks & $\begin{array}{l}\text { Albuminuria fall after the first week, } \\
\text { maintained also } 6 \text { weeks after } \\
\text { treatment cessation }\end{array}$ & $\begin{array}{l}\text { Szela- } \\
\text { chowska }^{46}\end{array}$ \\
\hline 15 & Type 2 diabetes & $\begin{array}{l}600 \text { lipoproteinlipase- } \\
\text { releasing units/day IM }\end{array}$ & 4 weeks & $\begin{array}{l}\text { Albuminuria fall in the } 60 \% \text { of } \\
\text { patients, reversed after }\end{array}$ & Sorrenti ${ }^{47}$ \\
\hline 20 & Type 2 diabetes & 100 mg/day & 4 months & $\begin{array}{l}\text { Significant reduction in albumin } \\
\text { excretion rate, fibrinogen and } \\
\text { blood pressure }\end{array}$ & Solini ${ }^{48}$ \\
\hline 53 & $\begin{array}{l}\text { Type } 2 \text { and type I } \\
\text { diabetes }\end{array}$ & $\begin{array}{l}600 \text { lipoproteinlipase- } \\
\text { releasing units/day IM }\end{array}$ & 3 weeks & $\begin{array}{l}\text { Significant reduction of } \\
\text { albuminuria in } 72 \% \text { of patients, } \\
\text { slower in type } 2 \text { diabetics }\end{array}$ & Skrha $^{49}$ \\
\hline 36 & Type I diabetes & $\begin{array}{l}600 \text { lipoproteinlipase- } \\
\text { releasing units/day IM } \\
5 \text { days/week }\end{array}$ & 3 weeks & $\begin{array}{l}\text { Significant reduction of } \\
\text { albuminuria in } 90 \% \text { of patients, } \\
\text { slower in macroalbuminuric patients }\end{array}$ & Dedov $^{50}$ \\
\hline 14 & Type I diabetes & $\begin{array}{l}60 \mathrm{mg} \text { vial of sulodexide/ } \\
\text { day for } 10 \text { days, and then } \\
\text { orally with } 25 \mathrm{mg} \text { capsules } \\
\text { twice a day for } 21 \text { days }\end{array}$ & 3 I days & $\begin{array}{l}\text { Significant reduction of } \\
\text { albuminuria with normalization in } \\
40 \% \text { of microalbuminurics } \\
\text { and } 25 \% \text { of macroalbuminurics }\end{array}$ & Poplawska ${ }^{51}$ \\
\hline 35 & $\begin{array}{l}\text { Type } 2 \text { and type I } \\
\text { diabetes }\end{array}$ & $\begin{array}{l}600 \text { lipoproteinlipase- } \\
\text { releasing units/day IM } \\
5 \text { days/week }\end{array}$ & 15 days & $\begin{array}{l}\text { Significant reduction of } \\
\text { albuminuria in } 70 \% \text { of patients, } \\
\text { persistent } 3 \text { weeks after } \\
\text { treatment cessation }\end{array}$ & Perusicová $^{52}$ \\
\hline 20 & $\begin{array}{l}\text { Type } 2 \text { and type I } \\
\text { diabetes }\end{array}$ & $\begin{array}{l}600 \text { lipoproteinlipase- } \\
\text { releasing units/day } \\
\text { IM } 5 \text { days/week }\end{array}$ & 3 weeks & $\begin{array}{l}\text { Quickly reversible } \\
\text { albuminuria in all patients }\end{array}$ & Zalevskaia $^{53}$ \\
\hline 20 & Type I diabetes & $\begin{array}{l}600 \text { lipoproteinlipase- } \\
\text { releasing units/day IM } \\
5 \text { days/week }\end{array}$ & 3 weeks & $\begin{array}{l}\text { Significant reduction of } \\
\text { albuminuria in } 70 \% \text { of patients, and } \\
\text { persisted in } 60 \% 6 \text { weeks after } \\
\text { drug discontinuation }\end{array}$ & Rasovskiī ${ }^{54}$ \\
\hline 20 & $\begin{array}{l}\text { Type } 2 \text { and type I } \\
\text { diabetes }\end{array}$ & $\begin{array}{l}600 \text { lipoproteinlipase- } \\
\text { releasing units/day IM } \\
5 \text { days/week }\end{array}$ & 3 weeks & $\begin{array}{l}\text { Significant reduction in albuminuria } \\
\text { and serum NAG activity }\end{array}$ & Skrha ${ }^{55}$ \\
\hline 20 & $\begin{array}{l}\text { Type } 2 \text { and type I } \\
\text { diabetes }\end{array}$ & $\begin{array}{l}60 \mathrm{mg} / \mathrm{d} \mathrm{IM} \\
100 \mathrm{mg} / \mathrm{d} \mathrm{PO}\end{array}$ & $\begin{array}{l}3 \text { weeks } \\
8 \text { weeks }\end{array}$ & $\begin{array}{l}\text { Albumin excretion rate reduced } \\
\text { after both treatment phases in } \\
\text { macroalbuminuric, but not } \\
\text { microalbuminuric patients }\end{array}$ & $\mathrm{Oksa}^{56}$ \\
\hline
\end{tabular}

(Continued) 
Table I (Continued)

\begin{tabular}{|c|c|c|c|c|c|}
\hline $\begin{array}{l}\text { Number of } \\
\text { patients }\end{array}$ & $\begin{array}{l}\text { Type of } \\
\text { patients }\end{array}$ & Dose & $\begin{array}{l}\text { Duration of } \\
\text { treatment }\end{array}$ & Main results & References \\
\hline 223 & $\begin{array}{l}\text { Type } 2 \text { and type I } \\
\text { diabetes }\end{array}$ & $\begin{array}{l}50 \mathrm{mg} / \mathrm{d}, 100 \mathrm{mg} / \mathrm{d} \text {, } \\
\text { or } 200 \mathrm{mg} / \mathrm{d} \mathrm{PO}\end{array}$ & 4 months & $\begin{array}{l}\text { Dose-dependent reduction in albumin } \\
\text { excretion rate }\end{array}$ & Gambaro $^{24}$ \\
\hline 60 & $\begin{array}{l}\text { Type } 2 \text { and type I } \\
\text { diabetes }\end{array}$ & $50 \mathrm{mg} / \mathrm{d} \mathrm{PO}$ & 12 months & $\begin{array}{l}\text { Albuminuria strongly reduced in all } \\
\text { patients vs controls and vs baseline }\end{array}$ & Achour $^{57}$ \\
\hline 45 & Type I diabetes & $120 \mathrm{mg} / \mathrm{d} \mathrm{PO}$ & 6 months & $\begin{array}{l}\text { Reduction in albuminuria and } \\
\text { NAG excretion, increase in renal } \\
\text { vascular function }\end{array}$ & Sulikowska ${ }^{58}$ \\
\hline 149 & $\begin{array}{l}\text { Obese type } 2 \\
\text { diabetics with } \\
\text { proteinuria resistant } \\
\text { to therapy with } \\
\text { ACEl or ARBs }\end{array}$ & $\begin{array}{l}200-400 \mathrm{mg} / \mathrm{d} \text { PO in } \\
\text { addition to } A C E l \text { or ARBs }\end{array}$ & 6 months & $\begin{array}{l}25.3 \% \text { and } 33.3 \% \text { of the patients } \\
\text { respectively in the two sulodexide } \\
\text { groups combined and in the } 200 \mathrm{mg} / \mathrm{d} \\
\text { group achieved a significant reduction or } \\
\text { normalization of albuminuria vs } 15.4 \% \\
\text { of the patients in the control group } \\
(P=0.26 \text { and } P=0.07 \text {, respectively })\end{array}$ & Heerspink $^{23}$ \\
\hline
\end{tabular}

Abbreviations: ACEl, angiotensin-converting enzyme inhibitor; ARB, angiotension-receptor blocker; IM, intramuscular; IV, intravenous; PO, by mouth; NAG, $\mathrm{N}$-acetyl-beta-glucosaminidase.

placebo; $P=0.075$ ), which was the more effective dose also in the largest published study. ${ }^{24}$ In particular, this trial clearly showed for the first time that sulodexide, $200 \mathrm{mg} /$ day for 4 months, was able to significantly decrease albuminuria (both versus placebo and baseline) independently of the concomitant administration of ACEI, but at an unspecified daily dosage. The decrease in the albumin excretion rate at the end of treatment was $40 \%$ and $46 \%$ versus baseline in patients receiving or not receiving ACEI, respectively $(P<0.05)$.

To the best of our knowledge only one trial has tested the effect of endovenous sulodexide administration on renal disease other than that caused by diabetes. ${ }^{25}$ In this trial the researchers enrolled patients with bioptic diagnosis of different glomerulonephritis, and observed after 1 month of treatment that overall $85 \%$ of patients experienced a significant reduction in proteinuria, which was significantly more impressive in patients with mesangiocapillary than in those with membrano- and mesangioproliferative glomerulonephritis. Moreover, the decline of proteinuria was more relevant in $\mathrm{GAG}(+)$ patients with important proximal tubular necrosis and moderate to severe myofibroblast infiltrates than in $\mathrm{GAG}(-)$ patients with mild interstitial involvement. $^{26}$

On the basis of the above-cited preclinical and clinical evidence, the use of sulodexide has also been suggested by experts for the treatment of serious chronic kidney diseases (CKD) other than those caused by diabetes. The most interesting is probably the management of the membranoproliferative glomerulonephritis type II (or dense deposit disease), a rare and serious renal genetic disease which affect 2 to 3 people per million and leads to renal failure within 10 years in $50 \%$ of affected children, with a worse prognosis after kidney transplantation than other genetic glomerulonephritis. ${ }^{27}$

However new trials have to be carried out to confirm these preliminary results and hypotheses.

\section{Other sulodexide pharmacological effects potentially useful in the diabetic CKD patient}

It is well known that diabetes patients are more likely to develop vein insufficiency and their related sequelae. The antithrombotic effects of sulodexide in patients affected by deep vein thrombosis ${ }^{28,29}$ and venous leg ulcers ${ }^{30,31}$ have been adequately investigated in different clinical trials. However, there is some evidence that sulodexide could also reduce the arterial disease risk, which is usually very high in diabetes patients with $\mathrm{CKD},{ }^{32}$ through a large number of pharmacological actions (Table 2).

Table 2 Potential cardiovascular beneficial effects of sulodexide and glycosaminoglycans

Antithrombotic action

Decrease of oxidative stress

Hypolipidemic actions

Prevention of glucose toxicity

Suppression of cellular inflammation

Antiproteinuric effects

Improvement of endothelial function and vascular elasticity

Interactions with AT-II signaling and RAS system 
Two different meta-analyses of the available clinical trials have show that sulodexide treatment improves the pain-free walking distance in patients affected by peripheral occlusive artery disease. ${ }^{33,34}$ This effect could be related to different sulodexide activities. First, the sulodexide-treated patients have higher peak flow and rest flow in the lower limbs. ${ }^{35}$ Moreover, sulodexide treatment improves the patient's lipid and hemorrheological profile. ${ }^{36}$ In particular, sulodexide improves the typical lipid components of metabolic syndrome, which is a predictor of both CKD worsening and cardiovascular disease risk in CKD patients. ${ }^{37}$ Recent data also support a significant anti-inflammatory action of sulodexide in the endothelial cells and a protective effect of the drug against glucose cytotoxicity. The experiments were performed on in vitro cultured human umbilical endothelial cells kept for 7 days in standard medium or in the same medium but supplemented with glucose. Sulodexide inhibited the intracellular generation of free radicals in a dose-dependent manner (by up to 32\%), as well as monocyte chemotactic protein-1 (MCP-1) (by up to 60\%) and IL-6 (by up to $69 \%$ ). Cells cultured in a medium with glucose generated more free radicals $(+20 \%)$ and released more MCP-1 $(+113 \%)$ and IL-6 (+26\%). Cell monolayers treated with glucose had a decreased ability to heal after mechanical injury $(-28 \%)$. All these glucose effects were reversed when cells were exposed to sulodexide simultaneously. ${ }^{19}$

In the long term, it is also possible that sulodexide exerts anti-atheromasic effects. In experimental models, sulodexide protects endothelium from external injuries as demonstrated by a reduced number of desquamated endothelial cells. ${ }^{38}$ Sulodexide could then stop the earliest phase of atherosclerosis, at the level of endothelial dysfunction, improving endothelium-dependent relaxation in small arteries. ${ }^{39}$ In a more advanced atherosclerosis phase, sulodexide inhibits neointimal proliferation after vascular injury of the carotid artery, as shown in an experimental model of restenosis after balloon angioplasty. ${ }^{40}$ Furthermore, in vitro heparin and heparinoids inhibit the proliferation of the vascular smooth muscle cells. ${ }^{41}$ This antiproliferative effect has also been supposed to be valid in humans, but only preliminary data are available. ${ }^{42}$

It has also been shown in humans that sulodexide treatment could also improve some clinical parameters in patients with vascular dementia. ${ }^{43}$ Consequently it has also been used to prevent ischemic cerebral damage in patients with antphospholipid antibodies. ${ }^{44}$

Finally, different GAGs have been reported to be of benefit to the ischemic myocardium by preserving contractile function and reducing tissue injury. In a rabbit model, sulodexide also attenuated myocardial ischemia/reperfusion injury and the deposition of C-reactive protein in areas of infarction without affecting hemostasis. ${ }^{45}$

The prognostic value of most of these observations has yet to be demonstrated, but they appear to be interesting working hypotheses, especially in patients with either CKD and preclinical signs of cardiovascular diseases.

\section{Conclusion}

Preclinical and clinical evidence directly or indirectly support the hypothesis that new, adequately designed, long-term studies need to be carried out to investigate the potential role of sulodexide for proteinuric CKD management in diabetes patients, in particular to understand which kind of patients could obtain the most clinical advantage from this therapeutic approach. Presently, there is a clear lack of preventive and therapeutic tools for proteinuric syndromes, and each new active compound needs to be evaluated, in order to widen the therapeutic arsenal against CKD. Considering the previously reported large spectrum of its pharmacological properties, sulodexide seems to be able to play an important role in the treatment of these patients because of its actions not only at the renal level, but also on the whole vessel tree, which is usually severely affected in diabetes patients with CKD.

In conclusion, a relatively large body of literature supports the antiproteinuric and nephroprotective effects of GAGs and sulodexide; however more basic clinical research is needed to understand which factors influence the drug's efficacy and, consequently, which patients could therefore benefit most from this treatment.

\section{Disclosure}

All authors received grants for scientific consultation on different topics by Alfa Wasserman SpA, Bologna, Italy, but no authors have a specific interest in the publication of this paper.

\section{References}

1. Martínez Castelao A. Advances in diabetes mellitus, diabetic nephropathy, metabolic syndrome and cardio-vascular-renal risk. Nefrologia. 2008;28 Suppl 5:79-84.

2. Radbill B, Murphy B, LeRoith D. Rationale and strategies for early detection and management of diabetic kidney disease. Mayo Clin Proc. 2008;83(12):1373-1381.

3. Cortinovis M, Cattaneo D, Perico N, Remuzzi G. Investigational drugs for diabetic nephropathy. Expert Opin Investig Drugs. 2008;17(10):14871500.

4. Raman R, Sasisekharan V, Sasisekharan R. Structural insights into biological roles of protein-glycosaminoglycan interactions. Chem Biol. 2005;12(3):267-277. 
5. Harvey SJ, Miner JH. Revisiting the glomerular charge barrier in the molecular era. Curr Opin Nephrol Hypertens. 2008;17(4):393-398.

6. Miner JH. Glomerular filtration: the charge debate charges ahead. Kidney Int. 2008;74(3):259-261.

7. Chen S, Wassenhove-McCarthy DJ, Yamaguchi Y, et al. Loss of heparan sulfate glycosaminoglycan assembly in podocytes does not lead to proteinuria. Kidney Int. 2008;74(3):289-299.

8. Wijnhoven TJ, Lensen JF, Rops AL, et al. Anti-proteinuric effects of glycosaminoglycan-based drugs. Curr Opin Mol Ther. 2007;9(4): 364-377.

9. Celie JW, Reijmers RM, Slot EM, et al. Tubulointerstitial heparan sulfate proteoglycan changes in human renal diseases correlate with leukocyte influx and proteinuria. Am J Physiol Renal Physiol. 2008;294(1): F253-F263.

10. Salmon AH, Neal CR, Sage LM, Glass CA, Harper SJ, Bates DO. Angiopoietin-1 alters microvascular permeability coefficients in vivo via modification of endothelial glycocalyx. Cardiovasc Res. 2009;83(1):24-33.

11. Ravera M, Re M, Weiss U, Deferrari L, Deferrari G. Emerging therapeutic strategies in diabetic nephropathy. JNephrol. 2007;20 Suppl 12:S23-S32.

12. Benck U, Haeckel S, Clorius JH, van der Woude FJ. Proteinurialowering effect of heparin therapy in diabetic nephropathy without affecting the renin-angiotensin-aldosterone system. Clin J Am Soc Nephrol. 2007;2(1):58-67.

13. Goh SY, Jasik M, Cooper ME. Agents in development for the treatment of diabetic nephropathy. Expert Opin Emerg Drugs. 2008;13(3):447-463.

14. Harenberg J. Review of pharmacodynamics, pharmacokinetics, and therapeutic properties of sulodexide. Med Res Rev. 1998;18(1):1-20.

15. Weiss R, Niecestro R, Raz I. The role of sulodexide in the treatment of diabetic nephropathy. Drugs. 2007;67(18):2681-2696.

16. Ruggeri A, Guizzardi S, Franchi M, Morocutti M, Mastacchi R. Pharmacokinetics and distribution of a fluoresceinated glycosaminoglycan, sulodexide, in rats. Part II: Organ distribution in rats. Arzneimittelforschung. 1985;35(10):1517-1519.

17. Lewis EJ, Xu X. Abnormal glomerular permeability characteristics in diabetic nephropathy: implications for the therapeutic use of low-molecular weight heparin. Diabetes Care. 2008;31 Suppl 2: S202-S207.

18. Gouverneur M, Broekhuizen L, Meuwese M, Mooij H, Stroes E, Vink H. Sulfated glycosaminoglycans restore glycocalyx barrier properties of cultured endothelial cells in hyperglycemia. FASEB J. 2008;22:1b83.

19. Shestakova MV, Chugunova LA, Vorontsov AV, Dedov II. The efficacy of sulodexide - a low-molecular heparin - in the therapy of diabetic nephropathy. Ter Arkh. 1997;69(6):34-37.

20. Karon J, Połubinska A, Antoniewicz AA, Suminska-Jasinska K, Breborowicz A. Anti-inflammatory effect of sulodexide during acute peritonitis in rats. Blood Purif. 2007;25(5-6):510-514.

21. Ciszewicz M, Polubinska A, Antoniewicz A, Suminska-Jasinska K, Breborowicz A. Sulodexide suppresses inflammation in human endothelial cells and prevents glucose cytotoxicity. Transl Res. 2009;153(3): $118-123$.

22. Kristová V, Lísková S, Sotníková R, Vojtko R, Kurtanský A. Sulodexide improves endothelial dysfunction in streptozotocin-induced diabetes in rats. Physiol Res. 2008;57(3):491-494.

23. Heerspink HL, Greene T, Lewis JB, et al; Collaborative Study Group. Effects of sulodexide in patients with type 2 diabetes and persistent albuminuria. Nephrol Dial Transplant. 2008;23(6):1946-1954.

24. Gambaro G, Kinalska I, Oksa A, et al. Oral sulodexide reduces albuminuria in microalbuminuric and macroalbuminuric type 1 and type 2 diabetic patients: the Di.N.A.S. randomized trial. J Am Soc Nephrol. 2002;13:1615-1625.

25. Gluhovschi G, Bozdog G, Petrica L, et al. Nephroprotection, part of multi-organprotection. TMJ. 2006;56:2-3.

26. Gluhovschi G, Schiller A, Raica M, et al. The effects of the therapy with natural lycosaminoglycans (sulodexide) on proteinuria in different types of glomerulonephritis. Med Biol. 2001;8(1): 26-30.
27. Smith RJ, Alexander J, Barlow PN, et al; Dense Deposit Disease Focus Group. New approaches to the treatment of dense deposit disease. J Am Soc Nephrol. 2007;18(9):2447-2456.

28. Cirujeda JL, Granado PC. A study on the safety, efficacy, and efficiency of sulodexide compared with acenocoumarol in secondary prophylaxis in patients with deep venous thrombosis. Angiology. 2006;57(1):53-64.

29. Errichi BM, Cesarone MR, Belcaro G, et al. Prevention of recurrent deep venous thrombosis with sulodexide: the SanVal registry. Angiology. 2004;55(3):243-249.

30. Nelson EA, Jones J. Venous leg ulcers. Clin Evid (Online). 2008; pii: 1902.

31. Coccheri S, Scondotto G, Agnelli G, Aloisi D, Palazzini E, Zamboni V; Venous arm of the SUAVIS (Sulodexide Arterial Venous Italian Study) Group. Randomised, double blind, multicentre, placebo controlled study of sulodexide in the treatment of venous leg ulcers. Thromb Haemost. 2002;87(6):947-952.

32. Rucker D, Tonelli M. Cardiovascular risk and management in chronic kidney disease. Nat Rev Nephrol. 2009;5(5):287-296.

33. Gaddi A, Galetti C, Illuminati B, Nascetti S. Meta-analysis of some results of clinical trials on sulodexide therapy in peripheral occlusive arterial disease. J Int Med Res. 1996;24(5):389-406.

34. Girolami B, Bernardi E, Prins MH, et al. Antithrombotic drugs in the primary medical management of intermittent claudication: a metaanalysis. Thromb Haemost. 1999;81(5):715-722.

35. Crepaldi G, Fellin R, Calabrò A, et al. Double-blind multicenter trial on a new medium molecular weight glycosaminoglycan. Current therapeutic effects and perspectives for clinical use. Atherosclerosis. 1990;81(3):233-243.

36. Gaddi AV, Cicero AF. Treatment of peripheral obstructive artery disease: a battle that could be winned also with drugs? Minerva Cardioangiol. 2005;53(6):605-610.

37. Ting SM, Nair H, Ching I, Taheri S, Dasgupta I. Overweight, obesity and chronic kidney disease. Nephron Clin Pract. 2009;112(3):c121-c127.

38. Kristová V, Kriska M, Babál P, Djibril MN, Slámová J, Kurtansky A. Evaluation of endothelium-protective effects of drugs in experimental models of endothelial damage. Physiol Res. 2000;49(1):123-128.

39. Kristová V, Lísková S, Sotníková R, Vojtko R, Kurtanský A. Sulodexide improves endothelial dysfunction in streptozotocin-induced diabetes in rats. Physiol Res. 2008;57(3):491-494.

40. Park HY, Kang S, Kim GY, et al. Inhibition of neointimal proliferation of rat carotid artery by sulodexide. J Korean Med Sci. 1997;12(3): 210-214.

41. Ciolino HP, Vijayagopal P, Radhakrishnamurthy B, Berenson GS. Heparin stimulates proteoglycan synthesis by vascular smooth muscle cells while suppressing cellular proliferation. Atherosclerosis. 1992;94(2-3):135-146.

42. Stivali G, Cerroni F, Bianco P, Fiaschetti P, Cianci R. Carotid Plaque Reduction After Medical Treatment. Circulation. 2005;112: e276-e277.

43. Parnetti L, Mari D, Abate G, et al. Vascular dementia Italian sulodexide study (VA.D.I.S.S.). Clinical and biological results. Thromb Res. 1997;87(2):225-233.

44. Rosca T. Methods of prevention of ischemic cerebral damages in patients with antiphospholipid antibodies. Oftalmologia. 2008;52(2):72-76.

45. Lauver DA, Booth EA, White AJ, Poradosu E, Lucchesi BR. Sulodexide attenuates myocardial ischemia/reperfusion injury and the deposition of C-reactive protein in areas of infarction without affecting hemostasis. $J$ Pharmacol Exp Ther. 2005;312(2):794-800.

46. Szelachowska M, Poplawska A, Topolska J, Kinalska I, Grimaldi M. A pilot study of the effect of the glycosaminoglycan sulodexide on microalbuminuria in type I diabetic patients. Curr Med Res Opin. 1997;13(9):539-545.

47. Sorrenti G, Grimaldi M, Canova N, Palazzini E, Melchionda N. Glycosaminoglycans as a possible tool for micro- and macroalbuminuria in diabetic patients. A pilot study. J Int Med Res. 1997;25(2):81-86.

48. Solini A, Vergnani L, Ricci F, Crepaldi G. Glycosaminoglycans delay the progression of nephropathy in NIDDM. Diabetes Care. 1997;20(5):819-823. 
49. Skrha J, Perusicová J, Pont'uch P, Oksa A. Glycosaminoglycan sulodexide decreases albuminuria in diabetic patients. Diabetes Res Clin Pract. 1997;38(1):25-31.

50. Dedov I, Shestakova M, Vorontzov A, Palazzini E. A randomized, controlled study of sulodexide therapy for the treatment of diabetic nephropathy. Nephrol Dial Transplant. 1997;12(11):2295-2300.

51. Poplawska A, Szelachowska M, Topolska J, Wysocka-Solowie B, Kinalska I. Effect of glycosaminoglycans on urinary albumin excretion in insulin-dependent diabetic patients with micro-or macroalbuminuria. Diabetes Res Clin Pract. 1997;38(2):109-114.

52. Perusicová J, Skrha J. The effect of sulodexide, a glycosaminoglycan, on albuminuria in diabetic patients. Vnitr Lek. 1997;43(11):748-752.

53. Zalevskaia AG, Astamirova KhS, Karpova IA, Popova SG. A trial of the use of the low-molecular heparin sulodexide in the therapy of diabetic nephropathy. Ter Arkh. 1998;70(3):71-74.
54. Rasovskii BL, Tarasov AV, Trel'skaia NIu, Severina TI, Chernykh EF. Sulodexide in the treatment of diabetic nephropathy. Klin Med. 1998;76(7):40-42.

55. Skrha J, Perusicová J, Kvasnicka J, Hilgertová J. The effect of glycosaminoglycan sulodexide on oxidative stress and fibrinolysis in diabetes mellitus. Sb Lek. 1998;99(2):103-109.

56. Oksa A, Pontuch P, Kratochvilova $H$. The effect of glycosaminoglycan sulodexide on albuminuria in patients with diabetes mellitus. Bratisl Lek Listy. 1999;100(9):486-489.

57. Achour A, Kacem M, Dibej K, Skhiri H, Bouraoui S, El May M. One year course of oral sulodexide in the management of diabetic nephropathy. J Nephrol. 2005;18(5):568-574.

58. Sulikowska B, Olejniczak H, Muszynska M, et al. Effect of sulodexide on albuminuria, NAG excretion and glomerular filtration response to dopamine in diabetic patients. Am J Nephrol. 2006;26(6):621-628.

\section{Publish your work in this journal}

The International Journal of Nephrology and Renovascular Disease is an international, peer-reviewed open-access journal focusing on the pathophysiology of the kidney and vascular supply. Epidemiology, screening, diagnosis, and treatment interventions are covered as well as basic science, biochemical and immunological studies. The journal welcomes original

\footnotetext{
Submit your manuscript here: http://www.dovepress.com/international-journal-of-nephrology-and-renovascular-disease-journal
}

research, clinical studies, reviews \& evaluations, expert opinion and commentary, case reports and extended reports. The manuscript management system is completely online and includes a very quick and fair peerreview system, which is all easy to use. Visit http://www.dovepress.com/ testimonials.php to read real quotes from published authors. 